\title{
Educational technology training workshops for mathematics teachers: An exploration of perception changes
}

\author{
Wilfred Wing Fat Lau and Allan Hoi Kau Yuen \\ The University of Hong Kong, Hong Kong SAR, China
}

\begin{abstract}
This study examined the effects of educational technology training workshops on perception changes of mathematics teachers. Three perceptions, namely, pedagogical orientation, efficacy, and liking in relation to technology integration, were explored in this study. Two research questions were addressed: Do educational technology training workshops affect teachers' perceptions of technology integration? What are the factors that influence changes of teachers' perceptions? The findings indicated that: (a) there were general effects of training on perception changes in pedagogical orientation and efficacy and (b) instructor, teachers' characteristics, pre-workshop experience, and workshop evaluation were significant factors influencing perception changes. While the overall findings mirrored those of previous studies examining teachers' beliefs about and attitudes towards technology integration in education, this study found that, compared with the younger mathematics teachers, the senior mathematics teachers' perceived efficacy increased but not their beliefs about the educational benefits of using technology after training. This suggests that the usual strategy of "one size fits all" does not appear to work and a more teacher-based training model is deemed necessary to engage all teachers in technology integration in education.
\end{abstract}

\section{Introduction}

It is believed that with the advent of information and communication technology (ICT), our society will be revolutionised in one way or another. As far as education is concerned, a number of international studies investigating the impact of ICT on pedagogical innovations have been conducted over the past few years (e.g., Law, Pelgrum, \& Plomp, 2008). Despites the differences in the frameworks and methodologies adopted in these studies, it is clear that ICT brings about changes in classroom practices in terms of curriculum, teachers' roles, students' roles, and learning outcomes to various extents. Educational changes have been tremendous in countries all over the world. Regardless of the differences in the nature of these changes, they all point to the ultimate target of transforming teaching and learning in schools so that students are better prepared for the challenges in the 21 st century. In parallel with this development is the availability of ICT in school environments. It is hoped that ICT can transform or even reform education in schools.

Arguably, educational technology training is necessary to prepare teachers to use technology in teaching. No doubt, technology causes significant changes in a number of school practices, and teachers always play a central role in instituting and sustaining changes in classroom practices. However, it has been observed that teachers' intention to change is affected by a myriad of factors such as their attitudes, beliefs, and school culture (Tay, Lim, Lim, \& Koh, 2012). Research has indicated that teacher professional development is considered to be the most effective strategy to promote teacher change that can improve student learning outcomes (Cwikla, 2004). However, many studies have followed a status-quo approach to research design (Forgasz, 2006; Pierce \& Ball, 2009) and thus, little is known about the impact of teacher professional development on teachers' perceptions of technology integration and the influence of demographic characteristics. Furthermore, while studies show that teachers are more confident in using technology and more convinced of the pedagogical benefits of technology as a result of teacher professional development (Bennison \& Goos, 2010; Hartsell, Herron, Fang, \& Rathod, 2009), it is still unclear whether teachers will eventually integrate technology into their daily practices. For those who do adopt technology, some may revert back to a traditional teacher-directed approach to teaching even after receiving educational technology training (Pierson, 2001).

As such, it is of the utmost importance to identify factors influencing technology adoption and formulate viable solutions to foster the use of technology in teaching as a sustained practice. This is the motivation for this study. This study was guided by the following two research questions: Do educational technology training workshops affect teachers' perceptions of technology integration? What are the factors that 
influence changes of teachers' perceptions? Perceptions here refer to the three views of technology: benefits of using technology in the learning and teaching of mathematics (pedagogical orientation) (Yuen, Lee, \& Law, 2009), self-confidence in using technology (efficacy) (Compeau \& Higgins, 1995; Yuen \& Ma, 2008), and an affinity for technology (liking) (Kluever, Lam, \& Hoffman, 1994; Selwyn, 1997; Yuen, Law, \& Chan, 1999). We chose these three perceptions since they have been shown to be instrumental in teachers' adoption of technology in education. In order to answer the research questions, quantitative evidence was gathered from a group of mathematics teachers who opted for a five-session training in the use of ICT in the learning and teaching of mathematics.

\section{Literature review}

The enthusiasm for ICT in education has been fuelled by many governments around the world as an initiative to boost student learning. For instance, the National Council of Teachers of Mathematics (NCTM) in the U.S. expressed its position on the role of technology in the learning and teaching of mathematics as follows:

Technology is an essential tool for learning mathematics in the 21 st century, and all schools must ensure that all their students have access to technology. Effective teachers maximize the potential of technology to develop students' understanding, stimulate their interest, and increase their proficiency in mathematics. When technology is used strategically, it can provide access to mathematics for all students. (NCTM, 2008)

In the U.K., the former British Educational Communications and Technology Agency (BECTA) identified some key benefits of using ICT in mathematics, such as greater collaboration between pupils, an increased focus on strategies and interpretation, fast and accurate feedback for pupils using ICT, and increased motivation amongst pupils (BECTA, 2003).

Ironically, mathematics teachers have not widely used technology in teaching. Results from an international comparative study of 22 educational systems around the world revealed that "In a majority of the participating systems, the percentage of teachers reporting ICT-use was higher for science teachers than for mathematics teachers within the same system" (Law et al., 2008, p. 167). In Hong Kong, Yuen, Law, Lee, and Lee (2010) found that $82 \%(S D=38 \%)$ and $81 \%(S D=39 \%)$ of science and humanities teachers had reported using ICT in their Grade 8 classes respectively, whereas the corresponding figure for mathematics teachers was only $70 \%(S D=46 \%)$. From the perspective of teacher professional development, more efforts are certainly needed to address the multi-faceted nature of technology integration into teaching practices. As argued by McDougall (2008), given the widespread access to technology in schools in many countries today, "there is a clear need for programs that address the more complex issues of curriculum integration of IT, transformation of education through using IT, and pedagogical strategies to exploit the potential of IT to support individual and social learning" (p. 472).

Teachers' perceptions towards technology is an important factor affecting the decision whether or not to adopt technology, and yet it is intriguing to find that perceptions appear to be malleable through training, in particular regarding teachers' self-efficacy, attitudes, and beliefs. Gningue (2003) found that the attitudes and beliefs of teachers who underwent a long-term professional development programme (a 15week, 45 hour-graduate course) on the use of the graphic calculator and the Geometer's Sketchpad changed significantly compared with their counterparts who were only given short-term training workshops (three workshops totalling 7 hours) with the same types of technology tools. Watson (2006) showed that educational technology training can enhance teachers' self-efficacy with respect to the use of the Internet in the classroom, and this effect still exists after seven years. Hartsell et al. (2009) reported a significant increase in confidence among middle school in-service mathematics teachers in using technology to solve mathematical problems after attending a four-week intensive professional development workshop on graphic calculators and other generic application software. However, it is noteworthy that positive perception changes among mathematics teachers may not necessarily occur after training. One study by Jimoyiannis and Komis (2007) indicated that after a nationwide basic ICT training programme focusing on the application of ICT in education, mathematics teachers remained negative about using ICT in education and were sceptical about the possible changes brought about by ICT in the school mathematics culture. 
It is generally believed that teachers differ in their perceptions of technology according to their own characteristics such as gender, age, and teaching experience. The extant literature abounds with studies on the effects of demographic variables on teachers' perceptions of technology (Pierce \& Ball, 2009; Zhou \& $\mathrm{Xu}, 2007)$. Surprisingly, there is a lack of research on changes of teachers' perceptions after receiving educational technology training even though these changes are the first major breakthrough for instructional improvement (Yuen, 2000). Mouza (2009) asserted that "few studies exist to date that demonstrate the impact of technology focused professional development on teacher learning and practice", and "even fewer studies have examined teacher learning and practice for more than a year to understand the sustainability and growth of professional development gains" (p. 1197). Thus, "research and evaluation of professional development about technology in instruction must take into account the depth, the breadth, and the precise focus of the professional development activities" (Lawless \& Pellegrino, 2007, p. 580).

Jimoyiannis and Komis (2007) found that across a number of subject specialties including mathematics, teachers' post-training beliefs about the role of ICT in education were influenced by their gender, age, and teaching experience. In general, male teachers held a more positive attitude towards ICT in education while female teachers held a more neutral or negative attitude. Younger teachers had higher confidence levels and were more positive towards ICT in education than senior teachers. The less experienced (those having 1-10 years of teaching experience) and the veteran teachers (those having more than 30 years of teaching experience) were positive about ICT in education compared with the highly experienced teachers (especially those having 20-30 years of teaching experience), who were mainly more negative. Rientiesa, Brouwerb, and Lygo-Bakera (2013) indicated that teachers from a range of disciplines including mathematics became more confident in terms of their own abilities to integrate technology into practices with pedagogical design principles after twelve weeks of technology training. In Polly and Orrill's (2012) study, teachers reported a gain in knowledge about technology and about the support provided by technology in mathematics teaching through the exploration of technology-rich mathematical tasks. Hohenwarter, Hohenwarter, and Lavicza (2008) showed that after two weeks of workshops involving training on the use of GeoGebra, there were no significant differences in any subjective difficulty ratings of the software, its tools, or its features in a group of in-service middle and high school mathematics teachers. However, in these studies, either the subject domain was not necessarily mathematics, or there was no comparison between teachers' pre- and post-training technology perceptions. To conclude, the current literature has only explored to a very limited extent how educational technology training and teachers' demographic data influence their post-training technology perceptions.

\section{Method}

\section{Educational technology training workshops}

The workshops aimed to enhance secondary school mathematics teachers' knowledge and abilities in using technology to design activities for the learning and teaching of mathematics. There were five sessions over five consecutive weeks with each session lasting for three hours. The sessions were designed with features that characterise effective professional development: content focus, active learning, coherence, duration, and collective participation (Desimone, 2009). Session 1 concerned the integration of ICT into mathematics education. It briefly introduced the latest ICT tools that were used to facilitate the learning and teaching of mathematics in local and overseas schools, and discussed strategies and good practices in the integration of ICT in the learning and teaching of secondary school mathematics. Session 2 focused on 2D and 3D dynamic geometry tools. The Geometer's Sketchpad, Cabri Geometry II Plus, and Cabri 3D were demonstrated and participants were given opportunities for hands-on practices with these software. In Session 3, graphing tools and computer algebra systems were introduced. Participants were asked to design learning and teaching activities using GeoGebra and Eigenmath. In Session 4, dynamic statistical tools, Fathom and Tinkerplots, were discussed in relation to exploratory data analysis and simulation of random processes. Again, learning and teaching activities were designed using these tools after instructors' demonstration. The final session introduced WebQuest as a web-based inquiryoriented learning tool for mathematical problem solving through an inquiry-oriented approach. Participants were also required to present their assignment in this session. Before the end of each session, participants were invited to complete a survey voluntarily as an evaluation of that session. 


\section{Participants}

Participants in the surveys were in-service secondary school mathematics teachers in Hong Kong. They voluntarily took part in the workshops as part of the fulfilment of their continuing professional development every year. Upon satisfactory completion of the workshops, each participant was awarded a certificate of attendance as well as 15 hours of professional training. One hundred teachers participated in the workshops, and 90 of them completed all five surveys after the sessions. Teachers chose the schedule of the workshops convenient to them, and they were thus assigned to four different classes taught by three experienced instructors. There were 25 teachers in each class. The majority of the participants were male (71.1\%). Most of them aged under 51 (91.9\%). Over half of them (62.2\%) had taught mathematics for over 10 years, and $55.6 \%$ of them mainly taught senior form students. A substantial number of the participants $(92.2 \%)$ had received prior training in ICT, and $64.4 \%$ had even received training in the use of ICT in the learning and teaching of mathematics. The sample was considered to be quite representative in view of the fact that there were far more male than female mathematics teachers, and mathematics teachers had on average 12 years of teaching experience in secondary schools in Hong Kong (Leung, Yung, Wong, Mok, \& Leung, 2010; Mullis, Martin, Foy, \& Arora, 2012).

\section{Data collection}

Data were collected online from five sets of questionnaires before the end of each session. The first questionnaire consisted of five sections with items on the following areas: demographic information (Part 1), perceptions of the use of ICT in mathematics (Parts 2 and 3), actual use of ICT in mathematics (Part 4), and session and instructor evaluation (Part 5). The last questionnaire was similar to the first except that the sections on demographic information and actual use of ICT in mathematics were deleted because the information had already been collected. For the second, third, and fourth questionnaires, only the section on session and instructor evaluation and one section on some software-specific evaluation were included (see Appendix for the five sets of questionnaires).

\section{Perceptions of technology integration}

Exploratory factor analyses were performed on the data in the first and fifth sets of questionnaires. Items concerning the perceptions of the use of ICT in mathematics (s1q7 to s1q19 in Set 1 and s5q1 to s5q13 in Set 5) were selected as they represented perceptions of the use of technology in mathematics education. However, one item in Set 1 (s1q17) and the corresponding one in Set 5 (s5q11) were removed from the analyses since they were considered to be irrelevant in this context. Also, two items in Set 1 (s1q7 and s1q10) and the corresponding ones in Set 5 (s5q1 and s5q4) were reverse coded, and their responses were manipulated before analyses. Principal component analysis with varimax rotation was used, and the results of the two sets of data are shown in Table 1. For Set 1, three factors, namely, pedagogical orientation, efficacy, and liking with Cronbach's alphas $0.872,0.904$, and 0.736 respectively were extracted. They explained $73.929 \%$ of variation in total. Similarly, for Set 5, the same three factors, which loaded on the same corresponding items, were extracted. Their respective Cronbach's alphas were 0.821 , 0.886 , and 0.569 , and the cumulative variance explained was $67.986 \%$. All the factors showed acceptable levels of reliability for exploratory purpose (Nunnally, 1978).

\section{Workshop evaluation}

This section explains the variables session workshop evaluation (SWE), session workshop instruction (SWI), and session instructor evaluation (SIE) of each session. The variable SWE contains items concerning some general evaluation of the session which are the same across all the sessions. The variable SWI includes items concerning some software-specific evaluation; for example, this session teaches the functionalities of Cabri/Geometer's Sketchpad. The variable SIE contains one single item concerning the performance of the instructor. In order to obtain the values of these three variables in each session, numerical responses from the relevant items of each variable were averaged. Definitions of the three variables in each session are shown in Table 2. 
Australasian Journal of Educational Technology, 2013, 29(4).

Table 1

Results of exploratory factor analysis for Set 1 and Set 5 data

\begin{tabular}{|c|c|c|c|}
\hline & $\begin{array}{c}\text { Factor } 1 \\
\text { (Pedagogical } \\
\text { Orientation) }\end{array}$ & $\begin{array}{c}\text { Factor } 2 \\
\text { (Efficacy) }\end{array}$ & $\begin{array}{l}\text { Factor } 3 \\
\text { (Liking) }\end{array}$ \\
\hline s1q9 (s5q3) & $0.868(0.846)$ & & \\
\hline s1q11 (s5q5) & $0.826(0.835)$ & & \\
\hline s1q18 (s5q12) & $0.801(0.737)$ & & \\
\hline s1q12 (s5q6) & $0.780(0.689)$ & & \\
\hline s1q19 (s5q13) & $0.750(0.597)$ & & \\
\hline s1q16 (s5q10) & & $0.881(0.866)$ & \\
\hline s1q15 (s5q9) & & $0.854(0.838)$ & \\
\hline s1q13 (s5q7) & & $0.796(0.829)$ & \\
\hline s1q14 (s5q8) & & $0.752(0.818)$ & \\
\hline s1q7 (s5q1) & & & $0.831(0.869)$ \\
\hline s1q10 (s5q4) & & & $0.686(0.680)$ \\
\hline $\mathrm{s} 1 \mathrm{q} 8(\mathrm{~s} 5 \mathrm{q} 2)$ & & & $0.682(0.314)$ \\
\hline Cronbach's alpha & $0.872(0.821)$ & $0.904(0.886)$ & $0.736(0.569)$ \\
\hline Eigenvalue & $3.442(3.107)$ & $3.181(3.464)$ & $2.248(1.587)$ \\
\hline $\begin{array}{l}\text { Cumulative variance } \\
\text { explained }(\%)\end{array}$ & $28.684(25.892)$ & $55.192(54.758)$ & $73.929(67.986)$ \\
\hline
\end{tabular}

Table 2

Definitions of the three variables SWE, SWI and SIE in each session

\begin{tabular}{|c|c|}
\hline Variable & Mean \\
\hline S1WE & s1q24 to s1q28 \\
\hline S1WI & s1q29 and s1q30 \\
\hline S1IE & s1q31 \\
\hline S2WE & $\mathrm{s} 2 \mathrm{q} 1$ to $\mathrm{s} 2 \mathrm{q} 5$ \\
\hline S2WI & $\mathrm{s} 2 \mathrm{q} 6$ to $\mathrm{s} 2 \mathrm{q} 8$ \\
\hline S2IE & $\mathrm{s} 2 \mathrm{q} 9$ \\
\hline S3WE & $\mathrm{s} 3 \mathrm{q} 1$ to $\mathrm{s} 3 \mathrm{q} 5$ \\
\hline S3WI & $s 3 q 6$ to $s 3 q 9$ \\
\hline S3IE & s3q10 \\
\hline S4WE & $s 4 q 1$ to $s 4 q 5$ \\
\hline S4WI & $\mathrm{s} 4 \mathrm{q} 6$ and $\mathrm{s} 4 \mathrm{q} 7$ \\
\hline S4IE & s4q8 \\
\hline S5WE & $\mathrm{s} 5 \mathrm{q} 14$ to $\mathrm{s} 5 \mathrm{q} 18$ \\
\hline S5WI & $\mathrm{s} 5 \mathrm{q} 19$ to $\mathrm{s} 5 \mathrm{q} 21$ \\
\hline S5IE & $\mathrm{s} 5 \mathrm{q} 22$ \\
\hline
\end{tabular}




\section{Results}

\section{Effects of training workshops on teachers' perceptions}

To investigate any possible effects of training on teachers' perception changes, the three factors previously extracted were compared before and after the training sessions. The items for each factor $(5$ items in factor 1 (pedagogical orientation), 4 items in factor 2 (efficacy), and 3 items in factor 3 (liking)) were averaged and these values represented the scores of these factors. Paired sample t-tests were performed on the three factors using pre- and post-training data. Results indicated that there were statistically significant effects of educational technology training on efficacy and pedagogical orientation ( $t=-3.630, \mathrm{p}<0.001$ and $t=-2.285, \mathrm{p}<0.05$ respectively) but not on liking. In general, participants showed higher perceived efficacy in using ICT in the learning and teaching of mathematics and believed that using ICT could benefit mathematics pedagogy more after training.

\section{Effects of instructor}

To investigate any possible effects of instructor on teachers' perception changes, paired sample t-tests were performed on the three factors using pre- and post-training data for each instructor. Three instructors were responsible for teaching four different classes. Instructor 1 was a university lecturer in mathematics education. Instructor 2 was a senior mathematics teacher with more than 24 years of teaching experience in a secondary school. Instructor 3 was a mathematics department panel head with about 19 years of experience of teaching secondary school students mathematics. All the instructors had received prior training in using ICT in teaching mathematics. Results indicated that only the perceived efficacy $(t=$ $2.787, p<0.05$ ) increased statistically for instructor 2 .

\section{Effects of teachers' characteristics}

To examine any possible effects of teachers' characteristics on teachers' perception changes, a series of paired sample t-tests were carried out based on different characteristics including gender, age, teaching experience, major classes taught, and ICT in mathematics training. Age was collapsed into three groups (21-30 years, 31-40 years, 41 years or above) and teaching experience into two groups (not more than 10 years or more than 10 years). We considered 10 years of teaching experience as the minimum necessary for the integration of ICT into mathematics teaching since it generally takes 10 years for teachers to gain the necessary level of expertise (Elliott, 2005). As shown in Table 3, statistically significant relationships existed between male gender and efficacy $(t=-3.189, p<0.01)$, female gender and pedagogical orientation ( $t=-2.179, p<0.05)$, age group 21-30 and efficacy $(t=-3.071, p<0.01)$, age group 21-30 and pedagogical orientation $(t=-3.162, p<0.01)$, age group 41 or above and efficacy $(t=-2.857, p<$ $0.01)$, teaching experience not more than 10 and efficacy $(t=-3.348, p<0.01)$, teaching experience not more than 10 and pedagogical orientation $(t=-2.735, p<0.05)$, junior class teachers and efficacy $(t=-$ $3.204, p<0.01)$, junior class teachers and pedagogical orientation $(t=-2.185, p<0.05)$, and teachers receiving no ICT in mathematics training and efficacy $(t=-3.697, p<0.01)$. Males tended to show higher perceived efficacy in using ICT in learning and teaching whereas females tended to believe that ICT benefited mathematics pedagogy more after the workshops. Younger teachers, aged between 21 and 30, showed an increase in their perceived efficacy and pedagogical orientation after training. For the senior age group (age 41 or above), only their perceived efficacy increased. Less experienced teachers with at most 10 years of experience showed increases in their perceived efficacy and pedagogical orientation. Similarly, teachers who predominantly taught junior classes showed an increase in their perceived efficacy and pedagogical orientation. Teachers with no training in using ICT in mathematics teaching demonstrated higher perceived efficacy at the end of the workshops. 
Table 3

Results of effects of gender, age, teaching experience, major classes taught, and ICT in mathematics training on teachers' perception changes

\begin{tabular}{|c|c|c|c|c|c|c|c|}
\hline & & \multicolumn{2}{|l|}{$\begin{array}{l}\text { Pre_Liking - } \\
\text { Post_Liking }\end{array}$} & \multicolumn{2}{|l|}{$\begin{array}{l}\text { Pre_Efficacy - } \\
\text { Post_Efficacy }\end{array}$} & \multicolumn{2}{|c|}{$\begin{array}{l}\text { Pre_Peda_Orien - } \\
\text { Post_Peda_Orien }\end{array}$} \\
\hline & & $\begin{array}{l}\text { Mean } \\
(S D)\end{array}$ & $t$ & $\begin{array}{l}\text { Mean } \\
(S D)\end{array}$ & $t$ & $\begin{array}{c}\text { Mean } \\
(S D)\end{array}$ & $t$ \\
\hline \multirow[t]{2}{*}{ Gender } & $\begin{array}{l}\text { Male } \\
(n=64)\end{array}$ & $\begin{array}{c}0.077 \\
(0.593)\end{array}$ & 1.028 & $\begin{array}{l}-0.200 \\
(0.497)\end{array}$ & $-3.189 * *$ & $\begin{array}{l}-0.062 \\
(0.365)\end{array}$ & -1.357 \\
\hline & $\begin{array}{l}\text { Female } \\
(n=26)\end{array}$ & $\begin{array}{l}-0.026 \\
(0.364)\end{array}$ & -0.359 & $\begin{array}{l}-0.192 \\
(0.584)\end{array}$ & -1.678 & $\begin{array}{l}-0.146 \\
(0.342)\end{array}$ & $-2.179 *$ \\
\hline \multirow[t]{3}{*}{ Age } & $\begin{array}{l}21-30 \\
(n=21)\end{array}$ & $\begin{array}{c}0.056 \\
(0.432)\end{array}$ & 0.589 & $\begin{array}{l}-0.345 \\
(0.515)\end{array}$ & $-3.071^{* *}$ & $\begin{array}{l}-0.178 \\
(0.258)\end{array}$ & $-3.162 * *$ \\
\hline & $\begin{array}{l}31-40 \\
(n=31)\end{array}$ & $\begin{array}{c}0.056 \\
(0.421)\end{array}$ & 0.724 & $\begin{array}{l}-0.083 \\
(0.555)\end{array}$ & -0.823 & $\begin{array}{c}0.020 \\
(0.264)\end{array}$ & 0.414 \\
\hline & $\begin{array}{l}41 \text { or above } \\
(n=38)\end{array}$ & $\begin{array}{c}0.036 \\
(0.675)\end{array}$ & 0.325 & $\begin{array}{l}-0.225 \\
(0.479)\end{array}$ & $-2.857^{* *}$ & $\begin{array}{l}-0.124 \\
(0.453)\end{array}$ & -1.669 \\
\hline \multirow[t]{2}{*}{$\begin{array}{l}\text { Teaching } \\
\text { Experience }\end{array}$} & $\begin{array}{l}\text { Not more than } 10 \\
(n=34)\end{array}$ & $\begin{array}{c}0.142 \\
(0.554)\end{array}$ & 1.497 & $\begin{array}{l}-0.301 \\
(0.525)\end{array}$ & $-3.348^{* *}$ & $\begin{array}{l}-0.133 \\
(0.284)\end{array}$ & $-2.735^{*}$ \\
\hline & $\begin{array}{l}\text { More than } 10 \\
(n=56)\end{array}$ & $\begin{array}{l}-0.012 \\
(0.521)\end{array}$ & -0.173 & $\begin{array}{l}-0.133 \\
(0.512)\end{array}$ & -1.930 & $\begin{array}{l}-0.058 \\
(0.398)\end{array}$ & -1.085 \\
\hline \multirow{2}{*}{$\begin{array}{l}\text { Major } \\
\text { Classes } \\
\text { Taught }\end{array}$} & $\begin{array}{l}\text { Junior } \\
(n=40)\end{array}$ & $\begin{array}{c}0.138 \\
(0.623)\end{array}$ & 1.395 & $\begin{array}{l}-0.250 \\
(0.494)\end{array}$ & $-3.204 * *$ & $\begin{array}{l}-0.113 \\
(0.328)\end{array}$ & $-2.185^{*}$ \\
\hline & $\begin{array}{l}\text { Senior } \\
(n=50)\end{array}$ & $\begin{array}{l}-0.028 \\
(0.455)\end{array}$ & -0.428 & $\begin{array}{l}-0.140 \\
(0.548)\end{array}$ & -1.754 & $\begin{array}{l}-0.060 \\
(0.389)\end{array}$ & -1.050 \\
\hline \multirow[t]{2}{*}{$\begin{array}{l}\text { ICT in } \\
\text { Maths } \\
\text { Training }\end{array}$} & $\begin{array}{l}\text { Yes } \\
(n=58)\end{array}$ & $\begin{array}{c}0.050 \\
(0.463)\end{array}$ & 0.811 & $\begin{array}{l}-0.127 \\
(0.541)\end{array}$ & -1.775 & $\begin{array}{l}-0.104 \\
(0.403)\end{array}$ & -1.950 \\
\hline & $\begin{array}{l}\text { No } \\
(n=32)\end{array}$ & $\begin{array}{c}0.022 \\
(0.655)\end{array}$ & 0.183 & $\begin{array}{l}-0.309 \\
(0.466)\end{array}$ & $-3.697 * *$ & $\begin{array}{l}-0.071 \\
(0.256)\end{array}$ & -1.544 \\
\hline
\end{tabular}

Note. ${ }^{*} p<0.05 .{ }^{* *} p<0.01 .{ }^{* * *} p<0.001$.

\section{Effects of pre-workshop experience}

To examine any possible effects of pre-workshop experience on teachers' perception changes, a series of paired sample t-tests were carried out using data collected from the three items "I make some ICT-based mathematics teaching materials on my own.", "I use ICT to supplement my teaching in class.", and "I search or try to use ICT-based mathematics teaching materials." Responses from the first item were collapsed into three groups (never, a few times, at least once a month), while those from the remaining two items were collapsed into two groups (never or a few times, at least once a month). As shown in Table 4, statistically significant relationships existed between the "never" group and efficacy for the first item $(t=-3.814, p<0.01)$; between the "never or a few times" group and efficacy $(t=-4.830, p<0.001)$ 
and between the "at least once a month" group and pedagogical orientation $(t=-2.424, p<0.05)$ for the second item; and between the "never or a few times" group and efficacy $(t=-4.584, p<0.001)$ and between the "at least once a month" group and pedagogical orientation $(t=-2.315, p<0.05)$ for the third item. Teachers who never made their own ICT-based mathematics teaching materials showed an increase in their perceived efficacy in using ICT in learning and teaching after the workshops. Teachers who occasionally used ICT to supplement their teaching in class showed an increase in their perceived efficacy. Frequent users of ICT (at least once a month) showed an increase in their pedagogical orientation. A similar pattern was observed in the responses for the third item. Teachers who occasionally searched or tried to use ICT-based mathematics teaching materials showed an increase in their perceived efficacy. Frequent searchers or users of ICT (at least once a month) showed an increase in their pedagogical orientation.

Table 4

Results of effects of pre-workshop experience on teachers' perception changes

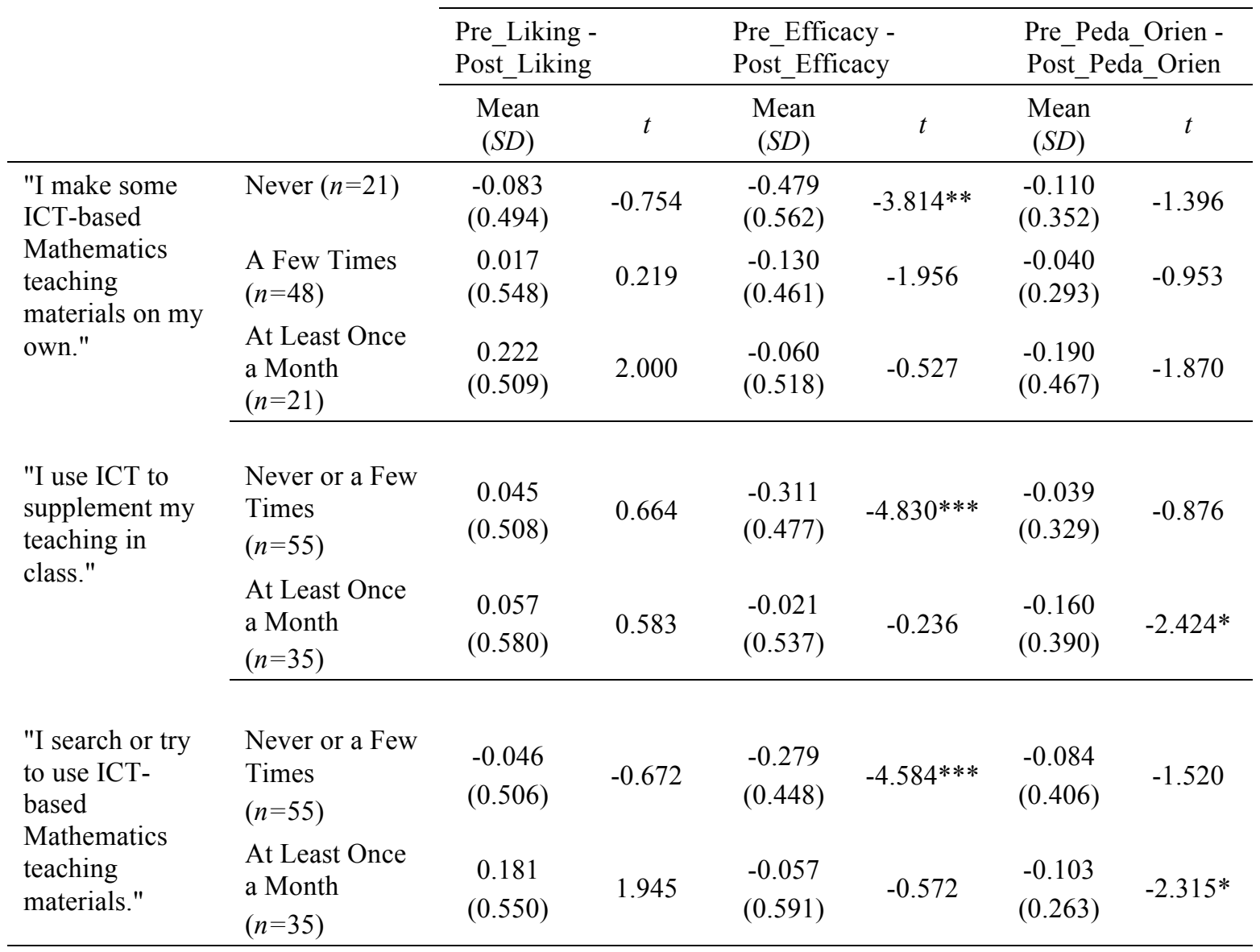

Note. ${ }^{*} p<0.05 .{ }^{* *} p<0.01 .{ }^{* * *} p<0.001$.

\section{Effects of workshop evaluation}

To investigate the influence of pre-workshop perceptions as well as workshop effects on post-workshop perceptions, multiple regressions on the three dependent variables, post-liking, post-efficacy, and postpedagogical orientation, were performed using the variables SWE, SWI, SIE, pre-liking, pre-efficacy, and pre-pedagogical orientation as the independent variables (there are totally 15 variables arising from SWE, SWI and SIE). Table 5 shows the significant predictors of the three dependent variables. For post-liking, only two predictors, S1WI $(t=-2.250, p<0.05)$ and pre-liking $(t=3.847, p<0.001)$, were found to be statistically significant. For post-efficacy, three statistically significant predictors, S2WE $(t=2.103, p<$ $0.05)$, pre-liking $(t=2.176, p<0.05)$, and pre-efficacy $(t=6.064, p<0.001)$, were found. For postpedagogical orientation, only one predictor, pre-pedagogical orientation, was statistically significant $(t=$ 
$6.207, p<0.001)$. It is obvious that pre-workshop perceptions were the major determinants of postworkshop perceptions.

Table 5

Multiple regression results predicting post-liking, post-efficacy, and post-pedagogical orientation from SWE, SWI, SIE, pre-liking, pre-efficacy, and pre-pedagogical orientation

\begin{tabular}{lll}
\hline & Post-Liking & \\
\hline Predictors & $\beta$ & $-2.250^{*}$ \\
S1WI & -0.307 & $3.847^{* * *}$ \\
Pre-liking & 0.490 & 0.508 \\
$R^{2}$ & & \\
\hline & Post-Efficacy & $t$ \\
\hline Predictors & $\beta$ & $2.103^{*}$ \\
S2WE & 0.294 & $2.176^{*}$ \\
Pre-liking & 0.214 & $6.064^{* * *}$ \\
Pre-efficacy & 0.584 & 0.707 \\
$R^{2}$ & & \\
\hline & Post-Pedagogical Orientation & \\
\hline Predictors & $\beta$ & $6.207^{* * *}$ \\
Pre-pedagogical orientation & 0.545 & 0.694 \\
$R^{2}$ & &
\end{tabular}

Note. ${ }^{*} p<0.05 .{ }^{* *} p<0.01 .{ }^{* * *} p<0.001$.

\section{Discussion}

Among various ICT training modes, many teachers preferred to attend workshops in updating their knowledge and skills on ICT (Yuen et al., 2010; Sivakumaren, Jeyaprakash, Geetha, \& Gopalakrishnan, 2011). This study reported the effects of educational technology training on teachers' perceptions of technology integration and the associated factors that influence changes of teachers' perceptions. Questions concerning the effectiveness of such training and its influencing factors are becoming increasingly important in this era for in-service teachers to harness the power of ICT to benefit learning and teaching. Our first research question inquired into the effects of educational technology training on teachers' perceptions of technology integration. With respect to this question, it was found that participants generally showed higher perceived efficacy in using ICT in learning and teaching, and believed that using ICT could benefit mathematics pedagogy more although there was no change in liking. This is in accordance with the findings of studies (Gningue, 2003; Hartsell et al., 2009; Watson, 2006) that demonstrated the general positive effect of training on teachers' perceptions. However, it contradicts the finding of Jimoyiannis and Komis (2007), which indicated negative perceptions of ICT use. It is possible that in the study by Jimoyiannis and Komis, teachers were taught generic software tools, while in the other studies by Gningue and Hartsell et al., some specific mathematics software tools were taught, and teachers' perceived efficacy regarding technology integration was thus increased. It is also likely that teachers today are more familiar with computer technologies than their peers six years ago, and the contradiction may reflect this change in perceptions.

The second research question sought to investigate the factors that influence changes of teachers' perceptions. With respect to this question, a number of demographic variables including gender, age, teaching experience, major classes taught, and ICT in mathematics training did matter. Overall, this pattern mirrors the findings of Jimoyiannis and Komis's (2007) study examining teachers' beliefs about and attitudes towards ICT in education using a sample of primary and secondary school teachers in Greece. Males tended to show higher perceived efficacy in using ICT in learning and teaching, whereas 
females tended to believe that ICT could benefit mathematics pedagogy more. These gender differences still appear to be relevant although there is evidence that the disparities are diminishing (Shapka \& Ferrari, 2003). Younger, junior class, and less experienced teachers showed an increase in their perceived efficacy and pedagogical orientation after the workshops. On the other hand, senior teachers and teachers with no training in using ICT in mathematics demonstrated higher perceived efficacy at the end of the training. This could be explained by the fact that younger teachers have earlier and more access to technology in schools and universities, and they are therefore more confident and ready to integrate technology into learning and teaching.

Pre-workshop experience is instrumental in perception changes. Teachers who occasionally searched or tried to use ICT-based mathematics teaching materials showed an increase in their perceived efficacy. Frequent searchers or users of ICT showed an increase in their pedagogical orientation. A plausible explanation for this phenomenon is that occasional ICT users are unfamiliar with the integration of technology into teaching, and the workshops can help them to establish initial confidence in using ICT. Frequent ICT users have already acquired a repertoire of knowledge and skills concerning ICT tools. Attending the workshops will not only raise their perceived efficacy, but also their tendency to use ICT in instruction. Pre-workshop perceptions remain the major determinants of post-workshop perceptions. This means that the influence of the variables SWE, SWI, and SIE on post-workshop perceptions was only moderate, and this result certainly warrants further discussion and investigation.

It is apparent from the results that, when compared with their younger counterparts, the senior mathematics teachers increased their perceived efficacy but not their beliefs about the benefits of incorporating ICT into their teaching after training. In other words, they were relatively less receptive to integrating technology into education. Although this finding has been shown in previous studies (Jimoyiannis \& Komis, 2006; Jimoyiannis \& Komis, 2007), practical strategies on how to deal with it are inadequate. For both teacher educators and researchers, there is an urgent need to formulate viable solutions to promote ICT-based pedagogical practices among the senior teachers, in particular to establish a need for using technology (Sturdivant, Dunham, \& Jardine, 2009). In view of this, it is important to examine two fundamental questions: Why do teachers need to use technology in their classrooms? Also, how do teachers decide to accept or reject using technology in their teaching? According to Kiraz and Ozdemir (2006), technology acceptance is related to four main factors: (1) the perceived ease of use of technology, (2) the perceived usefulness of technology, (3) the attitudes towards the use of technology, and (4) the frequency of use of technology. Experienced teachers would be more convinced if they were shown the benefits of using technology (the perceived usefulness of technology) before they really experimented with it in practice. Ottenbreit-Leftwich et al. (2012) argued that "what teachers find meaningful with regard to technology could be equated to knowledge of instructional problems that technology can help solve, knowledge of specific technology that can solve those instructional problems, and knowledge of how the technology can help solve those instructional problems within their own specific educational contexts" (p. 400). One way to achieve this purpose is through teachers witnessing the successful stories of other teachers. It can be accomplished in the form of experience sharing during training sessions. According to Zhao and Cziko (2001), this method can increase teachers' perceived need for technology adoption and increase their knowledge of what new practices look like. This is also in line with Bandura's (1997) idea of vicarious experience, which asserts that individuals can observe the behaviours of others and then perform the same actions (Straub, 2009).

It is evident from the structure of the workshops in this study that there was a strong emphasis on pedagogical knowledge (PK), technological knowledge (TK), and pedagogical content knowledge (PCK) of mathematics, but only little attention given to how technology can be integrated into teaching practices. The technocentric approach to educational technology training does not seem to be appealing to the experienced mathematics teachers. This points to the significance of a body of knowledge called technological pedagogical content knowledge (TPACK) (Mishra \& Koehler, 2006). Peeraer and Van Petegem (2012) found that technological pedagogical knowledge (TPK) is a significant predictor of the use of ICT for teaching and support of student learning. TPACK is defined as "that body of knowledge teachers needed for teaching with and about technology in their assigned subject areas and grade levels" (Niess et al., 2009, p. 7). In brief, TPACK is understood as the interconnection and intersection of content, pedagogy, and technology. Niess, Sadri, and Lee (2007) proposed a five-stage developmental model to incorporate a particular technology in the learning and teaching of mathematics, namely, recognizing (knowledge), accepting (persuasion), adapting (decision), exploring (implementation), and advancing 
(confirmation). While teachers are possibly at different stages of the model, they may utilise the model to assess their level of competency of mathematics TPACK and plan their teaching activities and professional development in instructional technology. For teacher educators, this model also provides a pathway to evaluate and plan their technology professional development programmes for pre-service and in-service mathematics teachers. In mathematics education, TPACK experience in which a teacher might be involved within a training programme should be as culturally relevant as possible, that is, teachers should consider "the cultural relevance of an instructional activity may well be a key to helping them to determine how to reach all students" (Grandgenett, 2008, p. 161).

Finally, educational research has been criticised for being unable to affect daily routines due to the misalignment between research and practice. While many studies have been devoted to the identification of drivers and inhibitors of technology use, teachers are still resistant to adopting technology in their classrooms. In the context of teacher professional development, Afshari, Abu Bakar, Wong, Abu Samah, and Foo (2009) noted that "traditional sit-and-get training sessions or one-time-only workshops have not been effective in making teachers comfortable with using technology or adept at integrating it into their lesson plans" (pp. 95-96). To tackle this problem, it has been advocated that researchers and practitioners should collaborate to identify significant learning and teaching problems and develop prototype solutions to these problems, and this is in fact the basic tenet of design-based research. This research methodology aims to "improve educational practices through iterative analysis, design, development, and implementation, based on collaboration among researchers and practitioners in real-world settings, and leading to contextually-sensitive design principles and theories" (Wang \& Hannafin, 2005, pp. 6-7), and is characterised by being "(a) pragmatic; (b) grounded; (c) interactive, iterative, and flexible; (d) integrative; and (e) contextual" (p. 7). It is a proactive response to bridge the gap between research and practice. In reality, as training has a minimal effect on teachers' beliefs about the educational benefits of using technology, teacher educators should discuss and work closely with teachers to understand any impediments to their decisions, and put their best efforts into helping teachers to progress through the various stages of technology acceptance and adoption over a prolonged period. For example, many experienced teachers are accustomed to more dependent forms of learning. It is then suggested that "professional development for experienced teachers should promote both autonomous and collaborative instructional decision-making while simultaneously encouraging open-minded consideration of new instructional methods, tools, and resources" (Harris, 2008, p. 267).

\section{Conclusion}

Extensive use of ICT has been introduced into secondary school curricula over the last decade. International studies have endeavoured to determine whether ICT has transformed learning and teaching in schools so that students are well prepared for the challenges of the 21 st century. As an educational innovation, ICT has made a radical impact on learning and teaching in the classrooms. Successful implementation of an innovation is a process not an event, developmental in nature, and a highly personal experience for each teacher (Chamblee, Slough, \& Wunsch, 2008). Thus, educators and researchers need to understand and manage the change process and the changes brought about by ICT. A number of aspects of the ICT implementation and teacher professional development in mathematics education require further investigation.

Issues related to teacher professional development have become a crucial component of nearly every education policy (Petras, Jamil, \& Mohamed, 2012). Teachers are always at the heart of educational changes and teacher professional development is widely recognised as the most effective strategy to promote teacher change. Effective technology integration in education is a complex and multi-faceted issue. This study identifies a number of parameters for technology adoption among in-service mathematics teachers. At the same time, the study indicates a gap between teachers' perceived efficacy and their beliefs about the educational benefits of using technology for the senior teachers. While this result reminds us of the need to improve educational technology training for in-service teachers, it also reveals a deeper issue in educational research regarding the nexus between research and practice. For example, Dalgarno and Colgan (2007) presented a study to validate the need for alternative teacher professional development models and the value of professional communities and knowledge acquired through formal and informal technology-facilitated learning. Wang and Reeves (2003) contended that "theories and principles that are tested in real contexts with rigorous studies will be informative to 
teachers, administrators, other researchers, and any other people who are concerned with these issues" (p. 62).

\section{References}

Afshari, M., Abu Bakar, K., Wong, S. L., Abu Samah, B., \& Foo, S. F. (2009). Factors affecting teachers' use of information and communication technology. International Journal of Instruction, 2(1), 77-104.

Bandura, A. (1997). Self-efficacy: The exercise of control. New York: Freeman.

BECTA. (2003). What the research says about using ICT in Maths? Retrieved from https://www.education.gov.uk/publications/eOrderingDownload/15014MIG2799.pdf.

Bennison, A., \& Goos, M. (2010). Learning to teach mathematics with technology: A survey of professional development needs, experiences and impacts. Mathematics Education Research Journal, 22(1), 31-56.

Chamblee, G. E., Slough, S. W., \& Wunsch, G. (2008). Measuring high school mathematics teachers' concerns about graphing calculators and change: A year long study. The Journal of Computers in Mathematics and Science Teaching, 27(2), 183-194.

Compeau, D. R., \& Higgins, C. A. (1995). Computer self-efficacy: Development of a measure and initial test. MIS Quarterly, 19(2), 189-211.

Cwikla, J. (2004). Show me the evidence: Mathematics professional development for elementary teachers. Teaching Children Mathematics, 10(6), 321-326.

Dalgarno, N. \& Colgan, L. (2007). Supporting novice elementary mathematics teachers' induction in professional communities and providing innovative forms of pedagogical content knowledge development through information and communication technology. Teaching and Teacher Education, $23,1051-1065$.

Desimone, L. M. (2009). Improving impact studies of teachers' professional development: Toward better conceptualizations and measures. Educational Researcher, 38(3), 181-199.

Elliott, T. (2005). Expert decision-making in naturalistic environments: A summary of research. Australia: DSTO

Forgasz, H. (2006). Factors that encourage or inhibit computer use for secondary mathematics teaching. Journal of Computers in Mathematics and Science Teaching, 25(1), 77-93.

Gningue, S. M. (2003). The effectiveness of long term vs. short term training in selected computing technologies on middle and high school mathematics teachers' attitudes and beliefs. Journal of Computers in Mathematics and Science Teaching, 22(3), 207-224.

Grandgenett, N. F. (2008). Perhaps a matter of imagination TPCK in mathematics education. In AACTE (Ed.), Handbook of Technological Pedagogical Content Knowledge (TPCK) for Educators, (pp. 145165). New York, NY: Routledge.

Harris, J. B. (2008). TPCK in in-service education: Assisting experienced teachers' "planned improvisations". In AACTE (Ed.), Handbook of Technological Pedagogical Content Knowledge (TPCK) for Educators, (pp. 251-271). New York, NY: Routledge.

Hartsell, T., Herron, S., Fang, H., \& Rathod, A. (2009). Effectiveness of professional development in teaching mathematics and technology applications. Journal of Educational Technology Development and Exchange, 2(1), 53-64. 
Hohenwarter, J., Hohenwarter, M., \& Lavicza, Z. (2008). Introducing dynamic mathematics software to secondary school teachers: The case of GeoGebra. Journal of Computers in Mathematics and Science Teaching, 28(2), 135-146.

Jimoyiannis, A., \& Komis, V. (2006). Exploring secondary education teachers' attitudes and beliefs towards ICT adoption in education. Themes in Education, 7(2), 181-204.

Jimoyiannis, A., \& Komis, V. (2007). Examining teachers' beliefs about ICT in education: Implications of a teacher preparation programme. Teacher Development, 11(2), 149-173.

Kiraz, E., \& Ozdemir, D. (2006). The relationship between educational ideologies and technology acceptance in preservice teachers. Educational Technology \& Society, 9(2), 152-165.

Kluever, R. C., Lam, T. C. M., \& Hoffman, E. R. (1994). The computer attitude scale: Assessing changes in teachers' attitudes toward computers. Journal of Educational Computing Research, 11(3), 251-256.

Law, N., Pelgrum, W. J., \& Plomp, T. (Eds.). (2008). Pedagogy and ICT use in schools around the world: Findings from the IEA SITES 2006 study. Hong Kong: CERC-Springer.

Lawless, K. A., \& Pellegrino, J. W. (2007). Professional development in integrating technology into teaching and learning: Knowns, unknowns, and ways to pursue better questions and answers. Review of Educational Research, 77(4), 575-614.

Leung, K. S. F., Yung, H. W. B., Wong, S. L. A., Mok, A. C. I., \& Leung, C. Y. C. (2010). The Hong Kong component of Trends in International Mathematics and Science Study (TIMSS) 2007. Hong Kong: The Hong Kong Centre for IEA Studies, Faculty of Education, The University of Hong Kong.

McDougall, A. (2008). Models and practices in teacher education programs for teaching with and about IT. In J. Voogt \& G. Knezek (Eds.), International Handbook of Information Technology in Primary and Secondary Education, (Vol. 1, pp. 461-474). New York, NY: Springer Science+Business Media.

Mishra, P., \& Koehler, M. J. (2006). Technological pedagogical content knowledge: A new framework for teacher knowledge. Teachers College Record, 108(6), 1017-1054.

Mouza, C. (2009). Does research-based professional development make a difference? A longitudinal investigation of teacher learning in technology integration. Teachers College Record, 111(5), 11951241.

Mullis, I. V. S., Martin, M. O., Foy, P., \& Arora, A. (2012). The TIMSS 2011 international results in mathematics. Chestnut Hill, MA: TIMSS \& PIRLS International Study Center, Boston College.

NCTM. (2008). The role of technology in the teaching and learning of mathematics. Retrieved from http://www.nctm.org/about/content.aspx?id=14233.

Niess, M. L., Ronau, R. N., Shafer, K. G., Driskell, S. O., Harper, S. R., Johnston, C.,... Kersaint, G. (2009). Mathematics teacher TPACK standards and development model. Contemporary Issues in Technology and Teacher Education, 9(1), 4-24.

Niess, M. L., Sadri, P., \& Lee, K. (2007). Dynamic spreadsheets as learning technology tools: Developing teachers' technology pedagogical content knowledge (TPCK). Paper presented at the meeting of the American Educational Research Association Annual Conference.

Nunnally, J. C. (1978). Psychometric Theory (2nd ed.). New York: McGraw-Hill.

Ottenbreit-Leftwich, A. T., Brush, T. A., Strycker, J., Gronseth, S., Roman, T., Abaci, S., ... Plucker, J. (2012). Preparation versus practice: How do teacher education programs and practicing teachers align in their use of technology to support teaching and learning? Computers \& Education, 59(2), 399-411. 
Peeraer, J. \& Van Petegem, P. (2012). The limits of programmed professional development on integration of information and communication technology in education. Australasian Journal of Educational Technology, 28(Special issue, 6), 1039-1056.

Petras, Y., Jamil, H., \& Mohamed, A. R. (2012). How do teachers learn: A study on the policy and practice of teacher professional development in Malaysia. KEDI Journal of Educational Policy, 9(1), 51-70.

Pierce, R., \& Ball, L. (2009). Perceptions that may affect teachers' intention to use technology in secondary mathematics classes. Educational Studies in Mathematics, 71(3), 299-317.

Pierson, M. E. (2001). Technology integration practice as a function of pedagogical expertise. Journal of Research on Computing in Education, 33, 413-429.

Polly, D., \& Orrill, C. (2012). Developing technological pedagogical and content knowledge (TPACK) through professional development focused on technology-rich mathematics tasks. Meridian, 15, 1-32.

Rientiesa, B., Brouwerb, N., \& Lygo-Bakera, S. (2013). The effects of online professional development on higher education teachers' beliefs and intentions towards learning facilitation and technology. Teaching and Teacher Education, 29, 122-131.

Selwyn, N. (1997). Students' attitudes toward computers: Validation of a computer attitude scale for 1619 education. Computers \& Education, 28(1), 35-41.

Shapka, J. D., \& Ferrari, M. (2003). Computer-related attitudes and actions of teacher candidates. Computers in Human Behavior, 19, 319-334.

Sivakumaren, K. S., Jeyaprakash, B., Geetha, V., \& Gopalakrishnan, S. (2011). ICT training for LIS professionals working in engineering institutions in Chennai: A study. International Research: Journal of Library \& Information Science, 1(1), 71-85.

Straub, E. T. (2009). Understanding technology adoption: Theory and future directions for informal learning. Review of Educational Research, 79(2), 625-649.

Sturdivant, R. X., Dunham, P., \& Jardine, R. (2009). Preparing mathematics teachers for technology-rich environments. Primus: Problems, Resources, and Issues in Mathematics Undergraduate Studies, 19(2), 161-173.

Tay, L. Y., Lim, S. K., Lim, C. P., \& Koh, J. H. L. (2012). Pedagogical approaches for ICT integration into primary school English and mathematics: A Singapore case study. Australasian Journal of Educational Technology, 28(4), 740-754.

Wang, F., \& Hannafin, M. J. (2005). Design-based research and technology-enhanced learning environments. Educational Technology Research \& Development, 53(4), 5-23.

Wang, F., \& Reeves, T. C. (2003). Why do teachers need to use technology in their classrooms? Issues, problems, and solutions. Computers in the Schools, 20(4), 49-65.

Watson, G. (2006). Technology professional development: Long-term effects on teacher self-efficacy. Journal of Technology and Teacher Education, 14(1), 151-165.

Yuen, H. K. (2000). Teaching computer programming: A connectionist view of pedagogical change. Australian Journal of Education, 44(3), 240-253.

Yuen, H. K., Law, N., \& Chan, H. (1999). Improving IT training for serving teachers through evaluation. In G. Cumming, T. Okamoto, \& L. Gomez (Eds.), Advanced Research in Computers and Communications in Education, (Vol. 2, pp. 441-448). Amsterdam: IOS Press. 
Yuen, H. K., Law, N, Lee, M. W., \& Lee, Y. (2010). The changing face of education in Hong Kong: Transition into the 21st century. Hong Kong: Centre for Information Technology in Education, The University of Hong Kong.

Yuen, H. K., Lee, M. W., \& Law, N. (2009). School leadership and teachers' pedagogical orientations in Hong Kong: A comparative perspective. Education and Information Technologies, 14(4), 381-396.

Yuen, H. K. \& Ma, W. K. (2008). Exploring teacher acceptance of e-learning technology. Asia-Pacific Journal of Teacher Education, 36(3), 229-243.

Zhao, Y., \& Cziko, G. A. (2001). Teacher adoption of technology: A perceptual control theory perspective. Journal of Technology and Teacher Education, 9, 5-30.

Zhou, G., \& Xu, J. (2007). Adoption of educational technology: How does gender matter? International Journal of Teaching and Learning in Higher Education, 19(2), 140-153.

Corresponding author: Wilfred Wing Fat Lau, wwflau@hku.hk

Australasian Journal of Educational Technology (C) 2013.

Please cite as: Lau, W. W. F., \& Yuen, A. H. K. (2013). Educational technology training workshops for mathematics teachers: An exploration of perception changes. Australasian Journal of Educational

Technology, 29(4), 595-611. 


\section{Appendix}

\section{Learning and Teaching of Mathematics with Information and Communication Technology in Secondary Schools}

\section{Workshop Evaluation Questionnaire}

\section{Part 1: Personal Demographics}

(s1q1) Gender: Male / Female

(s1q2) Age: $\square 21-30 \square 31-40 \square 41-50 \square 51$ above

(s1q3) Teaching Experience: $\square$ less than 1 year $\square \quad 1-5$ year(s) $\square \quad 6-10$ years $\square$ more than 10 years

(s1q4) Major Classes Taught: $\square$ Junior $\square$ Senior

(s1q5) I have received some training on using ICT in education. $\square$ No $\square$ Yes

(s1q6) I have received some training on using ICT in the learning and teaching of mathematics. $\square$ No

$\square$ Yes

Part 2: Please indicate the extent to which you agree or disagree with the following statements

$\mathrm{SD}=$ Strongly Disagree $\mathrm{D}=$ Disagree $\mathrm{U}=$ Undecided $\mathrm{A}=$ Agree $\mathrm{SA}=$ Strongly Agree

\begin{tabular}{|l|c|c|c|c|c|}
\hline & SD & D & U & A & SA \\
\hline (s1q7/s5q1) Using computers to work makes me anxious and nervous. & 1 & 2 & 3 & 4 & 5 \\
\hline (s1q8/s5q2) I like learning ICT. & 1 & 2 & 3 & 4 & 5 \\
\hline $\begin{array}{l}\text { (s1q9/s5q3) I believe using ICT in learning and teaching can enhance } \\
\text { student learning. }\end{array}$ & 1 & 2 & 3 & 4 & 5 \\
\hline $\begin{array}{l}\text { (s1q10/s5q4) I do not want to change my existing pedagogy because of } \\
\text { using ICT. }\end{array}$ & 1 & 2 & 3 & 4 & 5 \\
\hline $\begin{array}{l}\text { (s1q11/s5q5) I believe using ICT can benefit the learning and teaching of } \\
\text { mathematics. }\end{array}$ & 1 & 2 & 3 & 4 & 5 \\
\hline $\begin{array}{l}\text { (s1q12/s5q6) I believe using ICT in learning and teaching can arouse } \\
\text { students' interest in mathematics. }\end{array}$ & 1 & 2 & 3 & 4 & 5 \\
\hline
\end{tabular}

Part 3: Please indicate the extent to which you agree or disagree with the following statements

$\mathrm{SD}=$ Strongly Disagree $\mathrm{D}=$ Disagree $\mathrm{U}=$ Undecided $\mathrm{A}=$ Agree $\mathrm{SA}=$ Strongly Agree

\begin{tabular}{|l|c|c|c|c|c|}
\hline & SD & D & U & A & SA \\
\hline $\begin{array}{l}\text { (s1q13/s5q7) I have adequate computer knowledge to help me to use ICT in } \\
\text { learning and teaching. }\end{array}$ & 1 & 2 & 3 & 4 & 5 \\
\hline (s1q14/s5q8) I am confident that I can learn ICT myself. & 1 & 2 & 3 & 4 & 5 \\
\hline $\begin{array}{l}\text { (s1q15/s5q9) I understand how to integrate ICT in the learning and teaching } \\
\text { of mathematics. }\end{array}$ & 1 & 2 & 3 & 4 & 5 \\
\hline $\begin{array}{l}\text { (s1q16/s5q10) I can effectively use ICT to help students to learn } \\
\text { mathematics. }\end{array}$ & 1 & 2 & 3 & 4 & 5 \\
\hline $\begin{array}{l}\text { (s1q17/s5q11) Searching or making ICT-based mathematics teaching } \\
\text { materials is very time-consuming. }\end{array}$ & 1 & 2 & 3 & 4 & 5 \\
\hline $\begin{array}{l}\text { (s1q18/s5q12) Using ICT facilitates students' understanding of mathematics } \\
\text { concepts. }\end{array}$ & 1 & 2 & 3 & 4 & 5 \\
\hline (s1q19/s5q13) Using ICT can increase my teaching efficiency. & 1 & 2 & 3 & 4 & 5 \\
\hline
\end{tabular}


Part 4: Please indicate the extent to which you agree or disagree with the following statements

$\mathrm{N}=$ Never $\mathrm{R}=\mathrm{A}$ Few Times $\mathrm{S}=$ At Least Once a Month $\mathrm{O}=$ At Least Once a Week $\mathrm{V}=$ Almost Everyday

\begin{tabular}{|c|c|c|c|c|c|}
\hline & $\mathrm{N}$ & $\mathrm{R}$ & $\mathrm{S}$ & $\mathrm{O}$ & $\mathrm{V}$ \\
\hline (s1q20) I make some ICT-based mathematics teaching materials on my own. & 1 & 2 & 3 & 4 & 5 \\
\hline (s1q21) I use ICT to supplement my teaching in class. & 1 & 2 & 3 & 4 & 5 \\
\hline (s1q22) I use the computer room to conduct my mathematics lessons. & 1 & 2 & 3 & 4 & 5 \\
\hline (s1q23) I search or try to use ICT-based mathematics teaching materials. & 1 & 2 & 3 & 4 & 5 \\
\hline
\end{tabular}

\section{Part 5: Session Evaluation}

Please indicate the extent to which you agree or disagree with the following statements

$\mathrm{SD}=$ Strongly Disagree $\mathrm{D}=$ Disagree $\mathrm{U}=$ Undecided $\mathrm{A}=$ Agree $\mathrm{SA}=$ Strongly Agree

\begin{tabular}{|c|c|c|c|c|c|}
\hline & SD & D & $\mathrm{U}$ & A & SA \\
\hline$(\mathrm{s} 1 \mathrm{q} 24 / \mathrm{s} 2 \mathrm{q} 1 / \mathrm{s} 3 \mathrm{q} 1 / \mathrm{s} 4 \mathrm{q} 1 / \mathrm{s} 5 \mathrm{q} 14)$ The progress of this session is moderate. & 1 & 2 & 3 & 4 & 5 \\
\hline $\begin{array}{l}(\mathrm{s} 1 \mathrm{q} 25 / \mathrm{s} 2 \mathrm{q} 2 / \mathrm{s} 3 \mathrm{q} 2 / \mathrm{s} 4 \mathrm{q} 2 / \mathrm{s} 5 \mathrm{q} 15) \text { The learning objectives of this session are } \\
\text { clear. }\end{array}$ & 1 & 2 & 3 & 4 & 5 \\
\hline (s1q26/s2q3/s3q3/s4q3/s5q16) The exposition of this session is detailed. & 1 & 2 & 3 & 4 & 5 \\
\hline $\begin{array}{l}(\mathrm{s} 1 \mathrm{q} 27 / \mathrm{s} 2 \mathrm{q} 4 / \mathrm{s} 3 \mathrm{q} 4 / \mathrm{s} 4 \mathrm{q} 4 / \mathrm{s} 5 \mathrm{q} 17) \text { The content of this session suits the needs of } \\
\text { the current mathematics curriculum. }\end{array}$ & 1 & 2 & 3 & 4 & 5 \\
\hline $\begin{array}{l}\text { (s1q28/s2q5/s3q5/s4q5/s5q18) This session increases my knowledge on } \\
\text { using ICT in the learning and teaching of mathematics. }\end{array}$ & 1 & 2 & 3 & 4 & 5 \\
\hline $\begin{array}{l}\text { (s1q29) The session deepens my understanding of technology integration in } \\
\text { the learning and teaching of mathematics. }\end{array}$ & 1 & 2 & 3 & 4 & 5 \\
\hline $\begin{array}{l}\text { (s1q30) The session introduces me to some new application software in } \\
\text { mathematics education. }\end{array}$ & 1 & 2 & 3 & 4 & 5 \\
\hline (s1q31) The instructor helps me to understand the content of this session. & 1 & 2 & 3 & 4 & 5 \\
\hline $\begin{array}{l}\text { (s2q6) This session teaches the functionalities of Cabri/Geometer's } \\
\text { Sketchpad. }\end{array}$ & 1 & 2 & 3 & 4 & 5 \\
\hline $\begin{array}{l}\text { (s2q7) The session deepens my understanding of how Cabri/Geometer's } \\
\text { Sketchpad can be applied in teaching relevant mathematics concepts. }\end{array}$ & 1 & 2 & 3 & 4 & 5 \\
\hline (s2q8) The session deepens my understanding of dynamic geometry. & 1 & 2 & 3 & 4 & 5 \\
\hline (s2q9) The instructor helps me to understand the content of this session. & 1 & 2 & 3 & 4 & 5 \\
\hline (s3q6) This session teaches the functionalities of GeoGebra. & 1 & 2 & 3 & 4 & 5 \\
\hline $\begin{array}{l}\text { (s3q7) This session makes me acquainted with the basic applications of } \\
\text { GeoGebra. }\end{array}$ & 1 & 2 & 3 & 4 & 5 \\
\hline $\begin{array}{l}\text { (s3q8) The session deepens my understanding of mathematics graphing } \\
\text { tools. }\end{array}$ & 1 & 2 & 3 & 4 & 5 \\
\hline (s3q9) The session deepens my understanding of computer algebra systems. & 1 & 2 & 3 & 4 & 5 \\
\hline (s3q10) The instructor helps me to understand the content of this session. & 1 & 2 & 3 & 4 & 5 \\
\hline (s4q6) This session teaches the functionalities of Fathom/TinkerPlots. & 1 & 2 & 3 & 4 & 5 \\
\hline (s4q7) The session deepens my understanding of dynamic statistical tools. & 1 & 2 & 3 & 4 & 5 \\
\hline (s4q8) The instructor helps me to understand the content of this session. & 1 & 2 & 3 & 4 & 5 \\
\hline $\begin{array}{l}\text { (s5q19) This session makes me acquainted with the basic operations of } \\
\text { WebQuest. }\end{array}$ & 1 & 2 & 3 & 4 & 5 \\
\hline $\begin{array}{l}\text { (s5q20) The session deepens my understanding of how WebQuest can be } \\
\text { used to help students to learn mathematics. }\end{array}$ & 1 & 2 & 3 & 4 & 5 \\
\hline $\begin{array}{l}\text { (s5q21) The session deepens my understanding of web-based inquiry- } \\
\text { oriented learning. }\end{array}$ & 1 & 2 & 3 & 4 & 5 \\
\hline (s5q22) The instructor helps me to understand the content of this session. & 1 & 2 & 3 & 4 & 5 \\
\hline
\end{tabular}

